Innlegg på inntil $\mathbf{4 0 0}$ ord lastes opp i http://mc.manuscriptcentral.com/tidsskriftet.

Redaksjonen forbeholder seg retten til å foreta redaksjonelle endringer.

Forfattere av vitenskapelige artikler har tilsvarsrett (jf. Vancouver-gruppens regler).

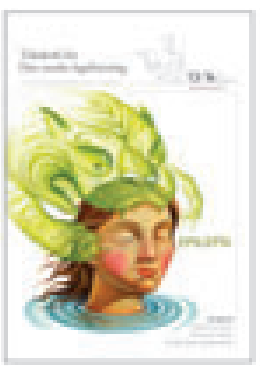

\section{Ikke-kontrollerte observasjonsstudier}

I Tidsskriftet nr. 13-14/2011 fikk vi presentert den nye metoden kateterbasert innsetting av klaffeproteser i pulmonalostiet (1). Artikkelen ble ledsaget av to kritiske ledere $(2,3)$.

Den type studier som Vegard Bruun Wyller har utført (ikke-kontrollerte observasjonsstudier), er vanlige i medisinsk forskning (4). De likner på registerstudier, de er hypotesegenererende og vil noen ganger initiere randomiserte studier.

Før gruppen startet studien, hadde de oppsøkt personer som har utført prosedyren, diskutert med dem hvilke problemer de hadde hatt og hvilke inntrykk de hadde av prosedyrens nytte. Videre har forfatterne fra tidligere lang erfaring med å sette inn perkutane klaffer og proteser i andre deler av hjertet.

I studien ble ti pasienter behandlet og fulgt over en periode på 1 1/2 år, med gode resultater. Stein Evensen foreslår at disse pasientene burde sendes til utlandet (2). Et EU-direktiv om mer flyt av pasienter over landegrensen vil underlette dette. Eksport av pasienter krever imidlertid god personlig kommunikasjon med behandlingssenteret fordi diagnostikk og etterbehandling må skje i Norge. Min erfaring er at eksport ofte initierer en papirmølle med klager og diskusjoner.

Er det eksperimentell, utprøvende eller etablert behandling? Ti pasienter er for lite til at man kan vurdere effekten av behandlingen. Vi har med hell kontaktet Sverige og Danmark for å få større materialer (4). Da blir man også tvunget til å skrive en forskningsprotokoll, kontakte etiske komiteer og opprette et skandinavisk dataregister. Skal man lage en randomisert studie hvor man sammenlikner med en annen etablert behandling? I dette tilfellet er Wyllers studie viktig fordi den viser lav komplikasjonsrate av perkutan klaffebehandling.

Hvis man skal kunne vise den kateterbaserte behandlingens overlegenhet med et lite materiale, må alternativet være meget dårlig. Uten en randomisert studie vil pasientene sannsynligvis oppfatte innsetting av en perkutan klaff som mer skånsomt enn kirurgisk inngrep.

Dersom man går for en registerstudie må man følge opp pasientene over mange år (4). En randomisert studie over to år vil ikke gi tilstrekkelig svar.

Mange av de første studiene på en mulig nyttig behandling i hjertemedisin er utført på den måten som Vegard Bruun Wyller og medarbeider har gjort. Det blir ofte opp til den enkelte lege og avdelingen å vurdere slike studier, hvor høy etisk standard med åpenhet og nøyaktig datainnsamling er det viktigste.

\section{Jan P. Amlie}

Medisinsk poliklinikk

Oslo universitetssykehus, Rikshospitalet

Jan P. Amlie (f. 1940) er dr.med. og spesialist i kardiologi og i indremedisin. Han er professor emeritus, Universitetet i Oslo.

Ingen oppgitte interessekonflikter.

\section{Litteratur}

1. Wyller VB, Aaberge L, Thaulow E et al. Perkutan innsetting av kunstig pulmonalklaff ved medfødt hjertefeil. Tidsskr Nor Legeforen 2011; 131: 1289-93

2. Evensen SA. Etikkvurdering ved innføring av ny behandling. Tidsskr Nor Legeforen 2011; 131: 1276.

3. Bretthauer M, Haug C. Hva er etablert behandling? Tidsskr Nor Legeforen 2011; 131: 1275.

4. Jensen MK, Almaas VM, Jacobsson L et al. Longterm outcome of percutaneous transluminal septal myocardial ablation in hypertrophic obstructive cardiomyopathy: a Scandinavian multicenter study. Circ Cardiovasc Interv 2011; 4 $256-65$.

Engelsk oversettelse av innlegget på www.tidsskriftet.no

\section{Samarbeid om å få flere leger ut!}

Som en av de største medisinske organisasjonene med mange utsendte unge leger hvert år ønsker Leger Uten Grenser å møte Legeforeningen for å diskutere hvordan vi kan standardisere og forenkle prosessen rundt godkjenning av internasjonal tjeneste i spesialisering.

Det er derfor med stor glede jeg leser Legeforeningens Hilde Engjoms svar i Tidsskriftet nr. 17/2011 både til mitt og til Tor H. Kristiansens innlegg vedrørende godkjenning av legearbeid ute (1-3).

Engjom påpeker at det er forholdsvis få søknader om å få arbeid i lavinntekts- og mellominntektsland godkjent som en del av en norsk spesialisering. Dette kan bero både på at en del av oss som har søkt om dette, har oppfattet det som en komplisert og tidkrevende prosess å få slik innsats godkjent, og på at mange ikke engang overveier muligheten for at slikt arbeid faktisk kan godkjennes!

Om Legeforeningen ønsker å være med på å legge til rette for at flere norske leger kan og vil arbeide ute, er en slik åpen holdning et stort skritt i riktig retning. Selvfølgelig må slikt arbeid utføres innenfor gitte rammer for å bli anerkjent, kravene til supervisjon og sikring av den enkelte leges rettigheter er absolutt nødvendig, og dette må kunne dokumenteres. Når man arbeider for organisasjonen Leger Uten Grenser, er disse kravene oppfylt, og dette vil sikkert også være tilfellet for flere andre arbeidsforhold ute - både for andre humanitære organisasjoner og prosjekt iverksatt av norske helseforetak.

Engjom oppfordrer flere leger som har erfaring fra tidligere eller pågående engasjement, til å sende en kort orientering til Legeforeningens utvalg for internasjonal helse. Dette håper jeg at flere av oss som har jobbet ute kan bidra med, slik at vi sammen med foreningen kan gjøre det litt enklere og kanskje også mer attraktivt for flere norske leger periodevis å jobbe ute.

\section{Karianne Flaatten}

Oslo universitetssykehus, Ullevål

Karianne Flaatten (f. 1977) er lege i spesialisering, Klinikk for akuttmedisin, Oslo universitetssykehus, Ullevål.

Oppgitte interessekonflikter: Forfatteren har vært på feltoppdrag for Leger Uten Grenser og var visepresident i Leger Uten Grenser Norge i 2010/2011.

Litteratur

1. Engjom H. Norske leger og humanitært arbeid Tidsskr Nor Legeforen 2011; 131: 1743-4.

2. Flaatten K. Humanitært arbeid må telle. Tidsskr Nor Legeforen 2011; 131: 337.

3. Kristiansen TH. Omkostninger ved humanitært arbeid. Tidsskr Nor Legeforen 2011; 131: 801-2. 